\title{
PEREMPUAN DALAM KONSTRUKSI SOSIAL RELIGIUS MASYARAKAT BALI
}

\author{
I Nyoman Duana Sutika \\ Program Studi Sastra Bali, Fakultas Ilmu Budaya UNUD \\ duanasutika01@gmail.com
}

\begin{abstract}
Religious social construction in the life of society in Bali gives advantages for men but vice versa for women in all aspects of life. Social construction strengthens myths, creates discrimination, marginalization, and oppression of women. Religious interpretations are conducted in constructions created by patriarchal societies, so women are always positioned as subordinate status. This cultural and patriarchal ideology clarifies women as the second class after men, as oppressed objects in all living structures. The image of women behind this cultural manifestation has become a heritage that accepted by balinese people until recently although feminism's insistence has been done entirely to strive for the emancipation and equality in all aspects of life.
\end{abstract}

Key words : women, social contruction, the people of Bali

\section{PENDAHULUAN}

Dalam berbagai era hingga sekarang secara mikroskopik terjadi perlakuan ketidakadilan terhadap perempuan, terakumulasi dalam berbagai bentuk pengetahuan, kuasa dan kapitalisme. Secara umum selama berabad-abad kaum perempuan ditindas oleh suatu sistem yang melibatkan, tidak saja kepentingan ekonomi, politik dan ideologi, tetapi juga agama. Konstruksi sosial religious atas jenis kelamin tersebut merupakan sebuah proses kontestasi dari dinamika ideologis suatu kebudayaan. Dengan demikian, tidak salah kalau agama 'dituduh' menjadi salah satu kekuatan yang melegitimasi ketidakadilan tersebut.

Agama yang diharapkan dapat memberikan, kenyamanan, dan keadilan bagi semua umat, justru di dalam ajarannya mengandung unsur-unsur ketidakberpihakan kepada kaum perempuan. Perempuan selalu dianggap sebagai kelas dua setelah laki-laki, bahkan laki-laki secara apriori melekatkan dan menempatkan perempuan sebagai objek yang dianggap lebih rendah dari laki-laki. Dalam misinya yang suci, agama yang menjadi tumpuan harapan dalam mencari keadilan, justru dalam kenyataannya membiarkan ketidakadilan terjadi sehingga agama sesungguhnya telah gagal atau tidak lagi menjadi tumpuan dan harapan di dalam mencari keadilan. Dalam teks-teks ajarannya banyak melegitimasi dan melanggengkan ketimpangan bagi kaum perempuan sebagaimana terdapat dalam teks Niti Sastra dan teks-teks sejenis lainnya. Agama bahkan mencatat adanya pengukuhan atas patriarki melalui paham dualistis (dikotomi) yang mengakibatkan adanya pembatasan ruang gerak bagi kaum perempuan. Meskipun jumlah perempuan dinyatakan Sarapung (1999: 43) lebih dari separoh bumi, banyak yang merasa tidak mampu dalam melaksanakan tugas, bukan saja disebabkan oleh tidak adanya persiapan yang baik tetapi juga karena telah terkondisi di dalam budaya yang pincang.

Dalam masyarakat Bali terbukti begitu banyak perempuan mampu melaksanakan tugas sebagaimana layaknya laki-laki, semisal menjadi sulinggih, pamangku (jan bangul), dan aparat penegak hukum lainnya, tetapi perempuan umumnya enggan memilih kesempatan ini untuk menjadi bidang yang ditekuninya. Hanya sebagian kecil saja yang memilih dan menekuni pekerjaan ini menjadi bidangnya. Sebaliknya pimpinan agama dan juga penegak hukum yang sebagian besar adalah laki-laki, menetapkan standar dan perempuan dituntut menyesuaikan diri dengan standar tersebut.

Kitab suci atau pedoman dalam lontar sering digunakan sebagai alasan untuk melanggengkan ketidakadilan mengenai ketentuan yang harus ditaati oleh perempuan di dalam kegiatan keagamaan/persembahyangan. Diberlakukannya ketentuan yang berbeda antara laki-laki dan perempuan dalam kegiatan keagamaan/ persembahyangan lebih kepada konsep bahwa tubuh perempuan lebih najis dari tubuh laki-laki, Hal ini karena perempuan mengalami siklus datang 
bulan (menstrasi) sehingga dilarang memasuki tempat-tempat yang dianggap suci oleh umat Hindu di Bali.

Berbagai macam ketidakadilan dalam masyarakat Bali, tidak dapat dilepaskan dari konteks nilai-nilai dan pandangan kultural serta ideologi patriarki yang selalu memosisikan perempuan sebagi objek dan berada di pihak yang tertindas dalam semua struktur kehidupan. Ketidakadilan bisa terjadi dalam berbagai ranah dan tempat, dari kehidupan sehari-hari hingga ke persoalan-persoalan besar, merasuk dalam ranah sosial-religius masyarakatnya.

Persoalan yang paling menonjol adalah pada hukum pewarisan yang sangat kental berpihak pada kaum laki-laki. Dengan hukum pewarisan yang berpihak pada laki-laki berimplikasi pada pengutamaan jenis kelamin bahwa anak laki-laki lebih mendapat prioritas daripada anak perempuan. Masyarakat Bali umumnya sangat mengharapkan adanya keturunan laki-laki yang akan menjadi pewaris dan meneruskan keturunan dalam keluarga. Adanya wacana bahwa 'anak laki-laki dan perempuan sama saja' sering hanya menjadi selogan/pameo semata untuk menutupi kekecewaan atas ketiadaan anak laki-laki yang diharapkan meneruskan garis keluarga. Inilah satu di antara beberapa jenis diskriminasi dalam konstruksi sosial religius masyarakat Bali yang akan diangkat dalam pembahasan berikut.

\section{PEMBAHASAN}

\section{Peran Ganda Perempuan dan Konstruksi Sosial Religius dalam Masyarakat Bali}

Citra perempuan sebagai ibu rumah tangga telah lama berakar terutama pada masyarakat tradisional yang hidup dari mata pencaharian bertani atau bercocok tanam. Segala aktivitas domestik berkenaan dengan pekerjaan rumah dianggap menjadi tanggung jawab perempuan atau seorang ibu, mulai dari memasak, membersihkan rumah (menyapu), merawat anak, dan yang berhubungan dengan kegiatan keagamaan lainnya. Beban kerja perempuan di sektor domestik ini menurut Kasiyan (2008: 64) merupakan akibat adanya konstruksi sosial budaya berkaitan dengan stereotif feminitas yang disandangnya. Betapa tidak, aktivitas yang dilakukan seorang perempuan (ibu) begitu padat mulai dari pagi sampai sore bahkan malam hari, sehingga dijuluki ibu rumah tangga. Perempuan umumnya cukup puas karena telah melakukan perannya sebagai ibu rumah tangga, sementara pasangannya mencari nafkah untuk kebutuhan rumah tangga. Ini yang tergambar terutama dalam kehidupan masyarakat tradisional.

Dalam masyarakat Bali modern keadaan perempuan di dalam mengatur dirinya dan perannya di dalam keluarga tidak mengalami perubahan yang terlalu signifikan. Ada peran-peran tertentu yang memang telah berubah, tetapi kebanyakan di antaranya tetap berjalan sebagai kebiasaan yang dianggap tradisi bagi masyarakatnya, seperti menyapu, merawat anak, urusan dapur dan beraneka jenis pekerjaan domestik yang dianggap menjadi tanggung jawab perempuan. Pekerjaan tersebut memang tidak harus dikerjakan oleh perempuan, tetapi konstruksi sosial masyarakat telah menganggap pekerjaan tersebut menjadi milik dan tanggung jawab kaum perempuan. Bagi perempuan karir umumnya, pekerjaan rumah tangga juga dianggap menjadi tanggung jawabnya. Hal ini banyak dilimpahkan ke pembantu rumah tangga yang kebanyakan juga dari kaum perempuan. Padahal pekerjaan bukanlah milik jenis kelamin tertentu, tetapi konstruksi sosial masyarakat Bali khususnya telah menjustifikasi bahwa pembagian peran tersebut dianggap sebagai peran menurut jenis kelamin. Keadaan yang mencoba membalikkan peran tersebut bahkan mendapat penilaian miring bahwasanya laki-laki tersebut dianggap tunduk pada pasangannya atau sebutan miring lainnya.

Konstruksi sosial yang dibuat masyarakat telah merugikan kaum perempuan dengan menyebut perempuan lemah lembut, cengeng, dan suka menangis (belengih). Dengan mengikuti gagasan Beauvoir (dalam Atmaja, 2010: 181) aspek lain yang amat mempengaruhi budaya patriarki, yakni memitoskan tubuh perempuan. Orang Bali menyebut jenis kelamin perempuan sebagai ' $l u h$ ' yang dalam bahasa Jawa Kuna berarti air mata. Mitos ini menimbulkan implikasi bahwa ruang gerak perempuan terbatas, yakni di sekitar rumah agar terhindar dari berbagai bentuk kekerasan yang dilakukan oleh laki-laki.

Dalam masyarakat Bali disebutkan Atmaja (2010: 168-169) bahwa masih berkembang mitos yang mewajibkan perempuan untuk menjaga keperawanannya, karena seorang gadis yang kehilangan keperawannya tidak dapat ditebus dengan apapun juga. Keperawanan adalah simbol kehormatan sehingga tidak mengherankan jika laki-laki merasa terhina kalau wanita yang dinikahinya tidak perawan lagi (sudah bolong). 
Inilah kekuatan ideologi patriarki yang telah mencekoki kaum perempuan atau para gadis yang berusaha sekuat tenaga menjaga keperawannya agar disebut sebagai gadis yang masih perawan (genten). Keperawanan menjadi salah satu kebanggan bagi perempuan untuk melanjutkan ke tingkat grehasta, menuju jenjang perkawinan. Tetapi hal ini tidak berlaku sama terhadap kaum laki-laki, yang tidak merasa bersalah meskipun dirinya tidak perawan lagi.

Diskriminasi juga terjadi pada sebutan rangda tiga bagi perempuan yang telah menjanda tiga kali tidak layak untuk diperistri lagi karena akan menimbulkan ekses yang kurang baik bagi pasangannya. Hal ini disebutkan oleh Ida Padanda Nabhe Gede Buruan pada seminar Prodi Sastra Bali tentang wariga, tanggal 18 Mei 2018. Istilah rangda tiga ini hanya berlaku untuk kasus yang terjadi pada perempuan saja dan kaum laki-laki bebas dari persoalan ini. Ini menandakan bahwa dalam tafsir agama terjadi berbagai macam konstruksi tentang perempuan yang dilakukan secara sepihak (patriarki), sebagaimana yang terdapat dalam teks Niti Sastra berikut;

\section{Lwirning tan reju ring jagat tri ganitanya tan abener ulahnya kawruhi, stri odwad kalawan lwah areju wilut lakunika pada tan wenang tuten, yan wwanten kamudacukul saka rikang watu mabener ulahing anggana, sangsiptanya wuwusku yatna sira sang sujana siniwi ring wadhu jana. (Mimbeng, dkk., 1997:40)}

\section{Terjemahan:}

Ketahuilah bahwa di atas dunia ini ada tiga hal yang jalannya tidak lurus, yaitu; wanita, akar, dan sungai, semua berbelok-belok jalannya tidak dapat dituruti. Jika sudah ada bunga kumuda tumbuh di batu, barulah wanita bisa benar. Pendeknya pesanku awaslah engkau jika bergaul dengan wanita, hai orang yang baik.

\section{Ring wang haywa manut I buddhinikanang para jana matemah winasaya, yan stri}

buddhi tinutaken pati temahanya hinirangiranging parampara,

(Mimbeng,dkk., 1997:40)
Tejemahan:

Jangan sekali-sekali menurut pikiran sembarang orang, agar jangan binasa. Jika kita menurut pikiran wanita, kita akan menemui ajal dan diperolok-olok orang selama-lamanya....

Teks di atas menegaskan bahwa di dalam sudut pandang agama perempuan dianggap sebagai objek, semata-mata disebabkan oleh pemahaman agama dan budaya yang menganut sistem patriarki. Pemahaman agama lebih menyudutkan kaum perempuan dengan label negatif bahwa hanya perempuan yang jalannya tidak pernah lurus, sementara laki-laki tidak termasuk di dalamnya. Agama telah menjastifikasi dan menyudutkan dengan menyebutkan kaum perempuan tidak punya pendirian teguh, mudah terpengaruh, sehingga disebut tidak pernah lurus alias bengkok. Justifikasi ini tentu mendapat bantahan dari kaum perempuan, lebih-lebih pada zaman sekarang kaum perempuan (feminisme) dengan sekuat tenaga memperjuangkan emansipasinya. Dalam konteks ini agama dianggap menjadi salah satu kekuatan yang dituduh menjadi sumber penyebab ketidakadilan yang terjadi pada perempuan. Agama menjadi paradoks pemenjaraan kaum perempuan sehingga mendapatkan stigmatisasi secara sepihak dari lawan jenisnya.

Begitu pula tradisi dan hukum adat tentang pewarisan yang berlaku di Bali cendrung memberikan pengutamaan pada anak laki-laki. Persoalan mengenai warisan, hak kepemilikan hanya berlaku untuk kaum laki-laki sementara perempuan hanya berhak sebatas ikut menikmati hasil dengan keputusan yang dibuat kaum laki-laki. Meminjam pendapatnya Panetje (1989: 111) terkait dengan waris, seorang anak perempuan pada hakekatnya hanya berhak untuk menikmati hasilnya belaka selama ia setia tinggal di rumah asalnya (tidak kawin). Windia (1995: 53-52) menegaskan dari perspektif aturan adat Bali bahwa wanita Bali yang beragama Hindu, dianggap tidak patut untuk menuntut pembagian warisan, kecuali dalam ha-hal tertentu, seperti setatusnya telah disamakan dengan laki-laki (kawin sentana).

Kaum perempuan tidak berhak menuntut warisan atau kepemilikan dari orang tuanya karena hukum pewarisan berlaku secara kapurusan (sistem kelaki-lakian). Hukum pewarisan semacam ini masih berlaku dalam masyarakat Bali umumnya. Begitu juga yang terjadi dalam hal perceraian, seringkali perempuan tidak dapat 
membela dan memperjuangkan hak-haknya, tentang pembagian harta, nafkah anak dan lainlain. Pada beberapa wilayah di Bali, perempuan juga sering terpaksa menerima perkawinan poligami karena ketergantungan dirinya secara ekonomi kepada suami, dan juga alasan lainnya.

Anak perempuan hanya berhak terhadap kepemilikan orang tuanya (bukan harta warisan) apabila ia diberikan secara sukarela (hibah), dalam bahasa Bali disebut bekel atau tetadtadan/bebaktan. Terkait persoalan waris sesungguhnya perempuan tidak pernah mendapat pengutamaan dan hal ini telah mendapatkan legitimasi secara agama dan hukum adat di Bali. Begitu pula yang menimpa perempuan tanpa pasangan atau tidak kawin selama hidupnya, ia hanya diberikan hak untuk ikut menikmati hasil warisan dari orang tuanya. Sementara apabila keadaan yang sama terjadi pada kaum laki-laki justru akan mendapat sepenuhnya warisan dari orang tuanya sebagai truna kuasa; seorang anak laki-laki yang telah dilibatkan dalam urusan adat/desa pakraman. Inilah salah satu bentuk marginalisasi perempuan yang sampai sekarang sulit dihindari oleh masyarakat Bali.

Tetapi sejak tahun 2010 perempuan mendapat angin segar karena Majelis Desa Pakraman mengeluarkan keputusan tentang hak waris, yang sedikit menguntungkan kaum perempuan. Majelis Desa Pakraman mengeluarkan keputusan bahwa perempuan berhak mewaris harta orang tuanya (bukan harta leluhurnya) yang pembagiannya $1 / 3$ untuk sanggah, $2 / 3$ dari warisan orang tuanya (punakaya) dibagi dua lagi: 1/3 menjadi hak anak perempuan dan 2/3 menjadi hak anak laki-lakinya. Dengan keluarnya keputusan Majelis Desa Pakraman ini tidak serta merta menguntungkan bagi perempuan Bali, karena selain sosialisasinya yang sangat lamban, juga sulitnya mengubah tradisi yang telah terlanjur kuat mengakar di Bali.

Terkait dengan pembagian tugas rumah tangga, perempuan dianggap sebagai pelaku pekerja domestik yang harus lebih banyak mengerjakan pekerjaan rumah tanga. Pekerjaan domestik dianggap menjadi milik kaum perempuan yang nilainya dianggap lebih rendah dibandingkan dengan pekerjaan lelaki. Bahkan setiap pekerjaan yang dilakukan perempuan dinilai hanya sebagai 'tambahan' yang juga sering mendapat bayaran lebih rendah dari pekerjaan laki-laki umumnya.

Dalam sudut pandang agama, Slokantara menyebutkan "yan hana wong angawe yadnya satus alah ikang dening anak suputra", artinya lebih utama mempunyai seorang anak yang pandai dan berbudi (suputra) daripada melakukan seratus kali yadnya/korban (Suprayitno, 1983: 7). Pernyataan ini seakan meniadakan perempuan meskipun putra masih mungkin diterjemahkan sebagai anak perempuan, tetapi lebih mengimplisitkan pada anak laki-laki. Hubungannya dengan konsep 'pitra/pitara' dalam upacara ngaben (pitra yadnya) di Bali mengandung makna peningkatan kedudukan preta (roh yang baru meninggal dan belum diupacarai) menjadi pitara (atman yang bebas dari ikatan suksma sarira). Pitara (bahasa Sanskerta) berasal dari kata 'pitr' yang artinya bapak, dan jamaknya 'pitaras' artinya nenek moyang atau leluhur (Jyoti, 2010:7). Orientasi dari pemaknaan kata 'pitara' ini juga telah mengabaikan perempuan seakan keberadaan 'pitara' dan juga nenek moyang/leluhur hanya berjenis kelamin laki-laki.

Kenyataan dalam masyarakat di daerah Kabupaten Buleleng dan Karangasen (di Bali), umumnya kelahiran anak perempuan saja, membuat orang tuanya menjadi gelisah karena anak perempuan dianggap tidak mempunyai hak mewarisi yang melanjutkan tradisi keluarga dan masyarakatnya. Hanya seorang laki-laki yang mewarisi sebagai purusa dan menjadi pelanjut atau meneruskan waris orang tuanya. Perempuan sungguh tidak berdaya dalam hukum pewarisan karena hukum juga lebih berpihak pada kaum lakilaki, yang kemudian tertuang dalam tradisi adat dan budaya masyarakatnya. Pada masyarakat tertentu di Bali, tradisi 'otonan' juga tetap dilakukan hanya untuk kaum yang menamakan dirinya seorang purusa yang identik dengan lakilaki. Sedangkan anak perempuan biasanya berhenti otonan saat mereka telah berumah tangga. Meskipun tradisi otonan ini tidak berlaku sama dalam masyarakat Bali umumnya

Selain tradisi adat, agama sering dianggap biang masalah atas terjadinya pelanggengan ketidakadilan perempuan tersebut. Pelanggengan ketidakadilan ini secara luas dalam agama bersumber dari watak agama itu sendiri berdasarkan pemahaman, penafsiran dan pemikiran keagamaan yang tidak mustahil dipengaruhi oleh tradisi dan kultur patriarki, ideologi kapitalisme maupun pandangan lainnya. Dengan demikian tafsir, interpretasi terhadap ajaran agama sangat dipengaruhi oleh kacamata pandang yang digunakan oleh penafsirnya.

Pada setiap agama menganjurkan asas penegakan prinsip keadilan. Namun demikian 
tafsiran agama mempunyai kedudukan yang sangat strategis dalam melanggengkan ketidakadilan perempuan. Pelanggengan ketidakadilan kaum perempuan ini secara tidak sadar juga dijalankan oleh ideologi dan kultur patriarki. Fakih (2006: 15) menyebutkan keadaan perempuan seperti ini tidak hanya terjadi di ranah publik tetapi juga terjadi pada rumah tangga (domestik), diperkuat oleh adat istiadat maupun tafsir keagamaan. Disebut pula oleh Fakih ( 2006: 74) bahwa selama berabad-abad dengan alasan doktrin agama kaum perempuan tidak boleh memimpin apapun.

Diskriminasi juga terjadi di dalam penerapan agama pada kasus pemakaian pamangku (jan bangul), bahwa masyarakat Bali lebih mengutamakan pamangku laki-laki, daripada pamangku perempuan, walaupun tidak berlaku di semua daerah di Bali. Secara sastra agama memang tidak ada larangan kaum perempuan untuk melakukan pemakuhan rumah atau sejenisnya. Tetapi menurut Nengah Medera (hasil wawancara tanggal, 26 April 2018) menyebutkan bahwa sering sekali di suatu daerah dresta (kebiasaan yang mengalir atau diwariskan dari orang tua, dan sima (kebiasaan) serta semaya (perjanjian masyarakat setempat) justru lebih kuat dibandingkan dengan pemahaman mereka terhadap sastra agama. Pemahaman dan keyakinan itulah yang dianggap benar dan dilaksanakan oleh masyarakatnya. Diamini oleh Wayan Suteja (hasil wawancara tanggal 24 April 2018) bahwa masyarakat sering tidak memahami sastra agama yang harusnya menjadi panduan, sehingga hambatan perempuan,seperti mengalami menstrasi justru dianggap akan menjadi penghambat, sehingga pamangku laki-laki menjadi pilihan dan diutamakan serta dianggap lebih pantas. Pemahaman sepotong masyarakat menganggap tentang rangkaian upacara" ngetok lait" di dalam upacara pemakuhan seharusnya memang dilakukan pamangku laki-laki (purusa), karena secara logika agama hanya seorang laki-laki (purusa) yang harusnya melakukan "ketok pasak/ngetok lait".

Pengutamaan laki-laki tidak hanya dalam justifikasi agama, tetapi di dalam karya besar seperti Ramayana, dan Mahabharata pun terjadi diskriminasi jenis kelamin, bahwa kelahiran anak laki-laki lebih diutamakan. Dalam Ramayana misalnya, tiga permaisuri raja Ayodya Dasarata (Dewi Kekayi, Dewi Kausalya, dan Dewi Sumitra) melahirkan tokoh Rama, Bharata, Laksmana dan Satrugna semuanya laki-laki. Begitu pula dalam cerita Mahabharata, baik pandawa dan kaurawa didominasi oleh kelahiran anak laki-laki. Tanpa menganggap ini sebagai suatu kebetulan tokoh perempuan yang dihadirkan seakan hanya sebagai pelengkap. Dengan mengambil seratus tokoh kaurawa, anak dari Drestarasta dan Dewi Gandari hanya lahir seorang anak perempuan pada urutan terakhir. Berdasarkan konstruksi sosial masyarakat Hindu umumnya, hal ini dianggap wajar saja karena selain penulis atau pengarang teks kedua karya besar di atas adalah seorang laki-laki, juga hasil karya tersebut untuk memenuhi kepentingan penguasa pada zamannya. Anak laki-laki dalam banyak hal dianggap lebih menentukan daripada anak perempuan, sehingga kekuasaan tertinggi pada zaman feodal/kerajaan mutlak di tangan lakilaki.

\section{Pelabelan Jenis Kelamin 'Leak' Dalam Masyarakat Bali}

Cerita Calonarang melekatkan perspektif masyarakat Bali dengan tuduhan bahwa dalam diri perempuan melekat energi ilmu magik terinspirasi dari mitos yang diciptakan oleh masyarakatnya sendiri. Cerita Calonarang merupakan lakon yang amat populer di kalangan masyarakat Bali karena cerita ini senantiasa dijadikan lakon dalam berbagai kesenian di Bali, seperti drama gong, arja, dan kesenian lainnya. Tokoh sentral cerita (mitos) ini adalah Calonarang (Walunateng Dirah) yang oleh masyarakat Bali dianggap 'inan leak' atau tokoh yang mempunyai ilmu leak pada tingkat yang tertinggi. Meskipun cerita Calonarang di Bali dipentaskan sebagai seni hiburan bersifat sekuler atau disebut balih-balihan, namun ikwal dan cikal bakal ilmu leak di Bali berawal dari cerita ini. Acapkali cerita ini dikaitkan dengan kehadiran rangda dan barong yang oleh masyarakat Bali menjadi simbol atau manifestasi rwa bineda atau dua hal yang dibedakan.

Masyarakat Bali umumnya percaya kaum hawa (perempuan) lebih mudah menguasai ilmu leak ini, terutama bagi mereka yang sakit hati terhadap sesamanya. Hal ini terjadi menurut Subagia (2011: 168) karena adanya kesamaan energi dan kesetaraan sifat alamiah kaum perempuan (hawa) dengan Hyang Bherawi sebagai pemberi ilmu leak tersebut, bahwa energi tertentu akan menarik energi sejenis dari alam raya ini.

Berbagai macam penafsiran mistis yang menyelimuti kehadiran tokoh rangda sebagai perwujudan Dewi Durga/Hyang Bherawi itu sendiri, mulai persepsi mistis tentang leak dan ilmu hitam lainnya. Rangda dalam kehidupan 
masyarakat Bali dianggap sebagai sosok perwujudan yang amat menakutkan bahkan dianggap sebagai sosok dengan kekuatan mistis tertinggi. Sebutan rangda tidak lagi dianggap sebagai personal biasa, tetapi ia lebih mewujud pada inpersonal yang agung dengan kekuatan yang super personal. Dalam makalah sebelumnya (2017), penulis mengangkat tulisan bertema 'diskriminasi cerita Calonarang terhadap citra ibu dalam masyarakat Bali'. Dalam tulisan tersebut disebutkan bahwa rangda adalah tokoh sentral yang paling menonjol dalam cerita calonarang dianggap ratuning leak sebagai puncak ilmu pangiwa (ilmu hitam) dalam kehidupan masyarakat Bali. Sebutan rangda menginspirasi orang terhadap sosok seram yang menakutkan sehingga orang merasa harus menjauhinya.

Tokoh Calonarang yang umum dikenal oleh masyarakat Bali serupa dengan wajah seseorang berambut gimbal terjurai, lidah menjulur, taring dan kuku mencengkram dengan susu bergayutan. Sebuah refleksi yang sungguh menyeramkan, menjijikkan, memalukan, untuk citra seorang perempuan. Calonarang ini sering mendapat pencitraan yang kurang beradab pada masyarakat Bali, terutama karena prilaku dan kemampuan ilmu pangleakan yang dimilikinya. Keadaan ini sering berimplikasi buruk bagi ibu-ibu (perempuan) yang bernasib sama dengan keaadaan Ni Calonarang, terutama pada status janda yang disandangnya. Meskipun secara kasat mata tidak ada hubungan sama sekali antara janda calonarang dengan kenyataan yang dialami oleh seorang ibu janda dalam kenyataan kehidupan ini.

Cerita Calonarang ini seakan memberikan sinyalemen penguatan persepsi dan label bahwa kaum perempuan lebih mudah untuk menguasai ilmu magik (pangleakan) dibandingkan dengan kaum laki-laki. Citra perempuan di balik manifestasi budaya seperti ini seakan telah menjadi warisan budaya yang diterima masyarakat (Bali) khususnya. Kaum hawa (perempuan) pun seakan tidak berdaya untuk melawan atau membantah sinyalemen tersebut. Kenyataan memang menunjukkan bahwa kaum perempuan sering dirugikan oleh tatanan masyarakat yang sering dilihat dari sudut pandang patriarki. Perempuan nampak biasa sebagai korban budaya karena kekuatan patriarki masyarakatnya.

Masyarakat Hindu Bali umumnya menuduh kaum perempuan lebih mudah dan punya potensi lebih besar untuk menguasai ilmu pangleakan (aji wegig/darma weci) yang sering disebut juga aneluh anesti anranjana. Persepsi semacam ini dikemukakan Rohmaniyah (dalam Surahmat: 2016: 226) karena praktik dan pemahaman agama bersifat androsentris menurut perspektif laki-laki. Banyak terjadi sinyalemen tentang kerentaan perempuan (dadong) nan bungkuk karena usianya yang usur dibayangi oleh sosok Calonarang sehingga terjadi sinyalemen negatif bagi perempuan tersebut (dicurigai bisa ngleak), dan tidak terjadi persepsi yang sama pada kerentaan laki-laki. Walaupun diketahui sesungguhnya ilmu pangleakan tersebut bisa dikuasai oleh baik laki-laki atau perempuan. Kecuali bagi mereka yang berprofesi sebagai 'dukun' (balian) sering juga laki-laki dianggap atau disinyalemen mempunyai ilmu pangleakan ini, yang bahkan konon dijual untuk lebih banyak kaum perempuan dalam berbagai bentuk barang/materi, seperti sabuk, bebuntilan, dan lain sebagainya.

Ilmu pangleakan sesungguhnya tidak jauh berbeda dengan ilmu lain yang juga bisa dipelajari dan dikuasai oleh siapapun juga. Tetapi persepsi yang melekat dalam diri masyarakat Bali seakan ilmu pengleakan ini melekat dalam diri perempuan renta sebagaimana tercermin dalam tokoh Calonarang. Leak menurut Subagia (2011: 94) hanyalah hasil konstruksi mental dalam wujud imajiner berupa penampakan mahluk halus hasil dari halusinasi. Senyatanya kata 'leak' adalah singkatan dari lelintihan aksara, sebuah metode spiritual dengan menggabungkan teknik pemutaran dasaksara, dikombinasikan dengan kanda pat dengan pembangkitan tujuh cakra dan pembangkitan kundalini.

Pada tingkat pemahaman, masyarakat Bali menyebut Tuhan-NYA dengan sebutan Ardanareswari, artinya Tuhan dalam wujud jenis kelamin setengah laki-laki dan setengah perempuan. Tetapi dalam wujudnya sebagai tri sakti; Brahma (sebagai pencipta), Wisnu (sebagai pemelihara), dan Siwa (sebagai pelebur) dianggap berjenis kelamin laki-laki yang mendomoinasi keyakinan Hindu, yakni Tuhan sebagai pencipta, pemelihara dan pelebur. Sementara peran istri dari wujud tri sakti ini tidak banyak dibicarakan. Sementara perwujudan Tuhan dalam manifestasinya sebagai Saraswati, Dewi Uma, Dewi Gangga dilambangkan sebagai wanita cantik dengan segala kelebihannya, sedangkan dalam wujudnya yang lain tergambar dalam wujud Dewi Durga, Men Geleh dengan proyeksi wajah yang menyeramkan. 


\section{SIMPULAN}

Dalam berbagai ranah, perempuan selalu ditempatkan pada urutan kedua setelah laki-laki. Hal ini dikuatkan oleh konstruksi sosial religius, dengan perspektif yang diciptakan dari sudut pandang laki-laki. Dengan demikian segala sesuatu dianggap wajar, adil dan telah memenuhi asas keadilan, walaupun sesungguhnya mengandung unsur-unsur diskriminasi, dan bentuk ketidakadilan lainnya. Ketidakmampuan perempuan di dalam memperjuangkan keadilan yang terkonstruksi ini diakibatkan oleh ketidakmampuan dirinya dalam bersaing dengan laki-laki. Dalam setiap era lakilaki masih tetap unggul sehingga belum mampu merubah konstruksi tersebut menjadi konstruksi sosial religious yang berkeadilan.

\section{DAFTAR PUSTAKA}

Atmaja, Nengah Bawa. 2010. Komodifikasi Tubuh Perempuan, Joged Ngebor Bali. Denpasar: Program Studi Magister dan Doktor Kajian Budaya Unud bekerjasama dengan Pustaka Larasan.

Fakih, Mansour.2006. Analisis Gender \& Transformasi Sosial. Yogyakarta. :Pustaka Pelajar

Fashri, Fausi. 2007. Penyingkapan Kuasa Simbol, Apropriasi Reflektif Pemikiran Pierre Bourdieu. Yogyakarta: Juxtapose.
Jyoti, Ida Rsi Bhujangga Waisnawa Putra Sara Shri Satya. 2010. Pedoman Tatacara Upacara Ngajum Kajang dan Pamrasan Dalam Upacara Ngaben. Denpasar: Pustaka Bali Post.

Kasiyan. 2008. Manipulasi dan Dehumanisasi Perempuan Dalam Iklan. Yogyakarta: Ombak

Mimbeng, I Gde. dkk. 1997. "Kakawin Niti Sastra dan Putra Sasana"; dikeluarkan oleh Pesantyan Sanatana Gita, Kecamatan Cakranegara, Kodya Mataram.

Sarapung, Elga.dkk (Editor). 1999. Agama dan Kesehatan Reproduksi. Jakarta: Pustaka Sinar Harapan.

Sihite,Romany.Perempuan/Kesetaraan/Keadilan . Jakarta: PT Raja Grafindo Persada.

Subagia, Jro Mangku Made. 2011. Menyingkap Tabir Leak. Denpasar: PT. Pustaka Manik Geni.

Suprayitno, Sumarti. 1983 Slokantara, Sebuah Teks Didaktik Jawa Kuna. Yogyakarta: Proyek Javanolohi BP3K

Surahmat, Fathur Rokhman. 2016. Politik Bahasa Penguasa. Jakarta: PT KOmpas Media Nusantara

Panetje, Mr. Gde. 1989. Aneka Catatan Tentang Hukum Adat Bali. Denpasar: Guna Agung. 